Egyptian Journal of Aquatic Biology \& Fisheries

Zoology Department, Faculty of Science,

Ain Shams University, Cairo, Egypt.

ISSN $1110-6131$

Vol. 23(4): 275 - 284 (2019)

www.ejabf.journals.ekb.eg

\title{
Adsorption of heavy metals from polluted water using low cost materials
}

\author{
Hala E. Ghannam ${ }^{1}$, Sayed A.A. Shama ${ }^{2}$, Abdelrahman S. Talab ${ }^{1}$, \\ Abdelazim M. El-Sharkawy ${ }^{2}$ and Karima O. Abbas ${ }^{2}$ \\ 1- National Institute of Oceanography and Fisheries (NIOF), Cairo, Egypt. \\ 2- Chemistry Department, Faculty of Science, Benha University, Egypt.
}

\author{
ARTICLE INFO \\ Article History: \\ Online: Oct. 20, 2019 \\ Keywords: \\ Activated carbon \\ Chitosan \\ Heavy metals \\ Polluted water \\ SEM \\ X-ray
}

Received: Oct. 3, 2019

Accepted: Oct. 18, 2019

\begin{abstract}
In this study chitosan and activated carbon (AC) were used as low cost materials for heavy metals removal and they were characterized by SEM, FTIR and X-ray. In the case of batch experiment chitosan and AC give a good removal of $\mathrm{Fe}, \mathrm{Cu}$ and $\mathrm{Zn}$ from aqueous solutions under the effects of sorbent dose, $\mathrm{pH}$, contact time, temperature and initial metal concentration. For application of the removal effect of chitosan and AC on water samples collected from River Nile at Helwan, Hawamdia and El-Kanater El-Khiria cities in greater Cairo, the two sorbents showed excellent removal of the industrial wastewater. Our results show the order of removal of the investigated heavy metals for chitosan were $\mathrm{Fe}>\mathrm{Pb}>\mathrm{Cu}>\mathrm{Zn}>\mathrm{Mn}$ while for $\mathrm{AC}$ were $\mathrm{Mn}>\mathrm{Cu}>\mathrm{Fe}>\mathrm{Pb}>\mathrm{Zn}$. So chitosan and $\mathrm{AC}$ can be used as a good absorbent materials cheap, effective and nontoxic for heavy metal removal.
\end{abstract}

\section{INTRODUCTION}

The greatest challenge of the modern age is water pollution with inorganic and organic pollutants which poses serious health risks to the human health and wildlife. Many studied have been done for wastewater treatment to make it clean, reusable, and to meet the increasing demands of fresh water. One of the famous strategies for water treatment is adsorption technology. The significant efforts been made over the years to develop highly selective and efficient adsorbent materials. Despite the great achievements, researchers are now focusing on developing the materials that are nontoxic, biocompatible, cost effective and efficient at the same time. Dendritic polymers are hyper branched macromolecules with unique three-dimensional structures decorated with a huge number of reactive end groups. They are relatively cheap, lesstoxic, easy to functionalize over other substrates and highly efficient (Sajida, et al., 2018). Water quality is the most essential and important resource on the earth which is continuously deteriorating due to contamination with domestic, agricultural and industrial activities which produce thousands of organic, inorganic and biological pollutants, so the need to find low cost adsorbent, environmental friendly, and easy regeneration is increasingly vital with the rapid development of industry (Wang and Zhuang, 2018). Currently, many scientists are focusing on the usage of agricultural wastes and crustacean byproducts as low cost adsorbents to solve the problems of water and environmental pollution (Menya, et al., 2018). Activated carbon is suitable for adsorption of chemicals, heavy metals, toxic chemicals, separation of gases, 
recovery of solvents, removal of organic pollutants and petrochemicals due to their high micro porosity, surface area, and adsorption capacity (Jyotsna, et al., 2005). Chitosan is basic polysaccharide and partially deacetylated polymer of glucosamine obtained from chitin by alkaline deacetylation (Ghannam, et al., 2016). In recent years chitosan-based adsorbents have attracted increasing attention in water and wastewater treatment due to its abundance and low price, as well as rich amino and hydroxyl groups. However, there are some drawbacks hindering its practical use, such as low mechanical strength, low solubility in acidic mediums, low adsorption capacity, and lack of selectivity (Wang and Zhuang, 2018). Thus, this study was aimed to prepare chitosan and activated carbon and characterized them by SEM, FTIR and X-ray, then, they were applied for removing of $\mathrm{Fe}, \mathrm{Cu}$ and $\mathrm{Zn}$ from synthetic wastewater. Another application was undertaken on natural pollution sources drain in the River Nile at Helwan, Hawmdia and El-El-Kanater El-Khiria El-Khiria cities during spring 2018. The effects of adsorbent dose, solution $\mathrm{pH}$, contact time and initial metal ion on adsorption efficiency concentration were investigated.

\section{MATERIALS AND METHODS}

\section{Preparation of chitosan}

Shrimp byproduct including (head, body shells and tails) were obtained from local market and they were extracted according to the method explained by (Toan, 2009). as follows: firstly shrimp byproduct was suspended in $4 \% \mathrm{HCl}$ at room temperature in the ratio of 1:14 (w/v) for $36 \mathrm{~h}$. Deproteinization of shells was done by treating the demineralized shells with $5 \% \mathrm{NaOH}$ at $90^{\circ} \mathrm{C}$ for $24 \mathrm{~h}$ with a solvent to solid ratio of $12: 1(\mathrm{v} / \mathrm{w})$. After the incubation time the shells were washed to neutrality in running tap water and sun dried. The product obtained was chitin which was deacetylatied by employing $70 \% \mathrm{NaOH}$ solution with a solid to solvent ratio of 1:14 (w/v) and incubated at room temperature for $72 \mathrm{~h}$ and then, the residues were washed with running tap water to neutrality and rinsed with deionized water, then filtered, sun dried and finely grinded to obtained chitosan (Dutta, et al., 2004).

\section{Preparation of activated carbon}

Rice husk was oven dried at $100^{\circ} \mathrm{C}$ overnight then conc $\mathrm{H}_{2} \mathrm{SO}_{4}$ was added in a weight/volume ratio of 1:1. The resulting black product was washed with water until free from excess acid and dried at $150 \pm 5^{\circ} \mathrm{C}$. The resulting black mass was kept in a furnace maintained at $400^{\circ} \mathrm{C}$ for 12 hours for activation. The carbon product obtained was ground well to fine powder which is used for all experiments (Baskaran, et al., 2010).

\section{Characterization of the adsorbent}

The physicochemical prosperities of chitosan and active carbon which were used as adsorbents in this work are shown in Table (1).

\section{Adsorbates: Metal ions}

Analytical grade iron (II) sulfate $\left(\mathrm{FeSO}_{4} \cdot 7 \mathrm{H}_{2} \mathrm{O}\right)$ copper (II) sulfate $\left[\mathrm{CuSO}_{4}\right.$ $\left.\cdot 5 \mathrm{H}_{2} \mathrm{O}\right]$ and zinc (II) sulfate $\left[\mathrm{ZnSO}_{4}\right]$, reagents from Sigma-Aldrich were used in the experiments. Stock solutions of $\mathrm{Fe}^{2+}, \mathrm{Cu}^{2+}$ and $\mathrm{Zn}^{2+}(1000 \mathrm{mg} / \mathrm{l})$ were prepared using double distilled water. Metal ion concentrations were determined using Inductively Coupled Plasma Optical Emission Spectroscopy (Varian Liberty II ICP-OES).

\section{Characterization of chitosan}

Moisture, protein and ash contents of obtained chitosan were determined according to the AOAC, (2007). Yield was determined according to Mohanasrini- 
vasan, et al., (2014). Water and fat binding capacity were measured according to Wang and Kinsella (1976).

\section{Degree of deacetylation (DD)}

FTIR instrument was used for the determination of DD of the three types of chitosan. The percentage of the acetylated amine group was determined by the following formula:

$\mathrm{DD}(\%)=100-\left[\left(\mathrm{A} 1629.85 \mathrm{~cm}^{-1}-\mathrm{A} 3450.65 \mathrm{~cm}^{-1}\right) / 1.33 \times 100\right]$ Struszczyk (1987)

Scanning electron microscopy (SEM) having a magnification range of 5,000 and accelerating voltage $20 \mathrm{kV}$ were used for characterization of prepared chitosan.

\section{$\mathrm{X}$-ray diffraction}

$\mathrm{X}$-ray diffraction (XRD) was measured at room temperature by using a Philips diffractometer using Model PW-3710. The patterns were progressed with Ni-filtered copper radiation $\left(\lambda=1.5418^{\circ} \mathrm{A}\right)$ at $30 \mathrm{kV}$ and $10 \mathrm{~mA}$ with a scanning speed of $2 \theta=$ $5 \% / \mathrm{min}$. The mean crystallites size were calculated using the Debye-Scherrer Eq. (1),

$$
D=\frac{K \lambda}{\beta \cos \theta}
$$

Where: $\mathrm{K}$ is a constant equal $0.9, \lambda$ is the wave length of the $\mathrm{Cu} \mathrm{K} \alpha$ radiation, $\beta$ is the half peak width of the diffraction peak in radiant. The different phases were recognized with the help of ASTM powder data files.

\section{FTIR spectroscopy}

The Fourier transform infrared (FT-IR) spectra were monitored via a single beam Thermo scientific Nicolet iS10 instrument. The samples were grounded with $\operatorname{KBr}(1: 100)$ to form tablets, and thus confined into the sample holder in the spectrometer cavity to record the measurements in the $4000-400 \mathrm{~cm}^{-1}$ region.

\section{Characterization of activated carbon}

Conductivity and $\mathrm{pH}$ values were analyzed using instrument CRISON Multimeter MM 40. Moisture and ash contents (\%) by mass, bulk density (g/L), specific gravity, water soluble matter, acid soluble matter were determined according to ISI (1989).

\section{Adsorption experiments}

Adsorption studies were performed by the batch technique. The $\mathrm{pH}$ values of solutions were adjusted by addition of $\mathrm{HCl}$ and $\mathrm{NaOH}$. A series of $50 \mathrm{ml}$ conical flasks were used. The flasks were shaken at $25,30,35$ and $40^{\circ} \mathrm{C}$ temperature and the shaking speed was $150 \mathrm{rpm}$. The adsorption experiments were carried out as follow: Experiment 1. The effect of adsorbent dose which ranged from 20 to $60 \mathrm{mg} / \mathrm{l}$. Experiment 2. The effect of initial concentrations which ranged from 5 to $30 \mathrm{mg} / \mathrm{l}$. Experiment 3. The effect of initial $\mathrm{pH}$ ranged from 4 to 9.

Experiment 4. Effect of temperature on the adsorption of ions: The adsorption experiments were conducted at four different temperatures $25,30,35$ and $40^{\circ} \mathrm{C}$ in a thermostat shaker machine.

Experiment 5. The effect of contact time which ranged from 30-360 minutes.

\section{RESULTS AND DISCUSSION}

\section{Physical and chemical characterization of chitosan and activated carbon}

Moisture, nitrogen, ash, yield, WBC, FBC and DD of the extracted shrimp chitosan recorded 1.70, 8.16, 0.60, 25.70, 1.25, 698 and 87\%, respectively. While, $\mathrm{pH}$, conductivity, moisture, ash, bulk density, specific gravity, WSM and ASM of the extracted activated carbon were 6.05, $0.29(\mathrm{mS} / \mathrm{cm}), 3.19(\%), 9.90(\%), 0.81(\mathrm{~g} / \mathrm{l})$, 
$0.92,1.17(\%)$ and $0.89(\%)$, respectively (Table 1$)$. The obtained results agree with those reported by Ghannam, et al., (2016).

Table 1: Physical and chemical properties of activated carbon and chitosan

\begin{tabular}{lclc}
\hline \multicolumn{1}{c}{ Activated carbon } & \multicolumn{2}{c}{ Chitosan } \\
\hline Properties & Values & Properties & $\%$ \\
pH & 6.05 & Yield (\%) & 25.70 \\
Conductivity (mS/cm) & 0.29 & Moisture (\%) & 1.70 \\
Moisture content (\%) & 3.19 & Nitrogen $(\%)$ & 8.16 \\
Ash content (\%) & 9.90 & Ash (\%) & 0.60 \\
Bulk density (g/L) & 0.81 & WBC (\%) & 1.25 \\
Specific gravity & 0.92 & FBC (\%) & 698 \\
Water soluble matter (WSM), \% & 1.17 & DD (\%) & 87 \\
Acid soluble matter (ASM), \% & 0.89 & & \\
\hline
\end{tabular}

\section{Characterization of the adsorbents}

Scanning electron micrograph (SEM)

The microstructure SEM images of chitosan showed non-smooth and nonhomogenous surface while for the activated carbon the surface was smooth, with few cracks or voids (Figure 1).
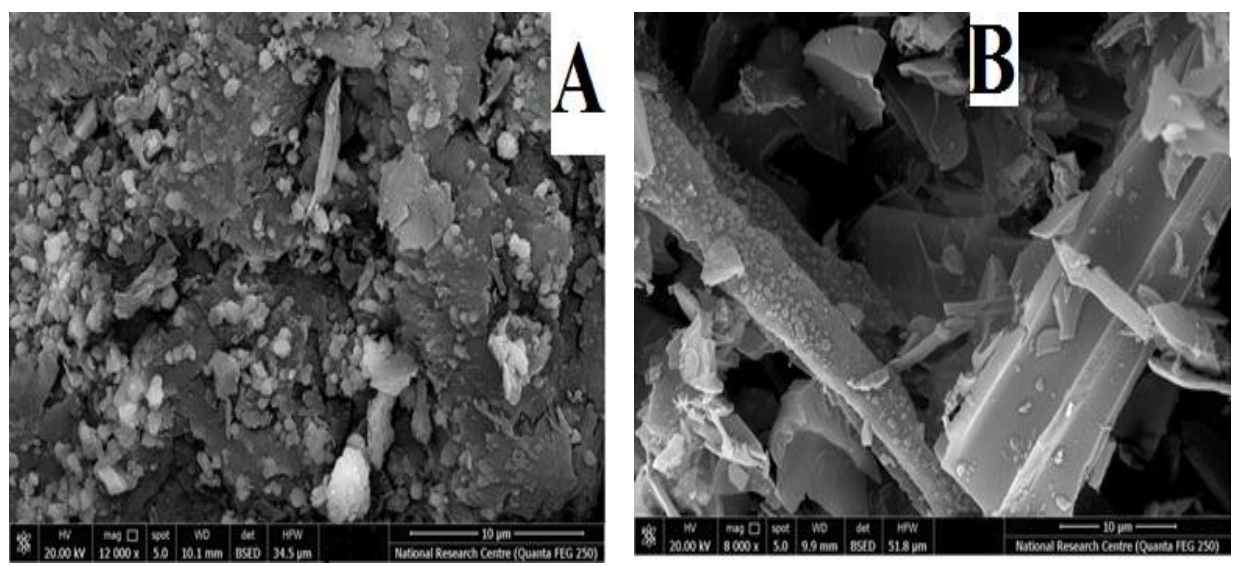

Fig. 1: SEM image of (A) chitosan and (B) activated carbon.

\section{Surface functional group analysis}

FTIR analyses for chitosan and activated carbon in order to identify the appearance and disappearance of functional groups were given in Tables ( 2 and 3 ) and represented graphically in Figures (2 and 3).

Thus, FTIR spectra of chitosan and activated carbon showed different peaks of different functional groups according to their corresponding wave numbers. The absorption bands at 3410 and $3427 \mathrm{~cm}^{-1}$ are assigned to $\mathrm{O}-\mathrm{H}$ groups which present in phenols, alcohols and carboxylic acids were in the chitosan and activated carbon. Also absorption bands at 2930 and $2921 \mathrm{~cm}^{-1}$ indicate C-O stretching in methyl and methylene groups appeared in chitosan and activated carbon. The absorption bands for the adsorbents at 1650 and $1615 \mathrm{~cm}^{-1}$ corresponds to $\mathrm{C}=\mathrm{C}$ stretching of olefins. The band at $1420 \mathrm{~cm}^{-1}$ for chitosan and $1422 \mathrm{~cm}^{-1}$ for activated carbon is due to $\mathrm{C}=\mathrm{O}$ stretching mode of the carbonyls, carboxylic acids, and lactones. The absorption bands at 703 and $1047 \mathrm{~cm}^{-1}$ for chitosan and activated carbon maybe due to ethers, esters, carbonyl groups, and phenol groups. Finally, the absorption band at $577 \mathrm{~cm}^{-1}$ is due to the $\mathrm{C}-\mathrm{Cl}$ group. The obtained FTIR analysis showed that, the surface of chitosan and activated carbon have acidic functional groups which improves the metal 
adsorption such as, alcohol, carboxyl and carbonyl groups and this result agree with those reported by Edwin (2008).

Table 2: Possible assignment of chitosan

\begin{tabular}{lccl}
\hline \multicolumn{1}{c}{ Functional class } & Band position/cm & Intensity & \multicolumn{1}{c}{ Assignment } \\
\hline Alcohols & 3410 & Strong & O-H (H-bonded), usually broad \\
Carboxylic & 2930 & Weak & -COO-H (very broad) \\
Alkenes & 2880 & Weak & C=C (symmetry reduces intensity) \\
Aliphatic aldehydes & 1650 & Strong & C=O (saturated aldehyde) \\
Aromatics & 1420 & Strong & C-C (in-ring) \\
Thiocarbonyl & 1200 & Strong & C=S \\
Esters & 703 & Strong & S-OR \\
\hline
\end{tabular}

Table 3: Possible assignment of activated carbon

\begin{tabular}{lccl}
\hline \multicolumn{1}{c}{ Functional class } & Band position/cm & Intensity & \multicolumn{1}{c}{ Assignment } \\
\hline Alcohols & 3427 & Strong & O-H (H-bonded), usually broad \\
Carboxylic & 2921 & Strong & -COO-H (very broad) \\
Aliphatic aldehyde & 1651 & Variable & C=C (symmetry reduces intensity) \\
Aromatics & 1422 & Weak & C-C (in-ring) \\
Esters & 1047 & Strong & S-OR \\
Alkyl halide & 577 & Weak & C-Cl \\
\hline
\end{tabular}

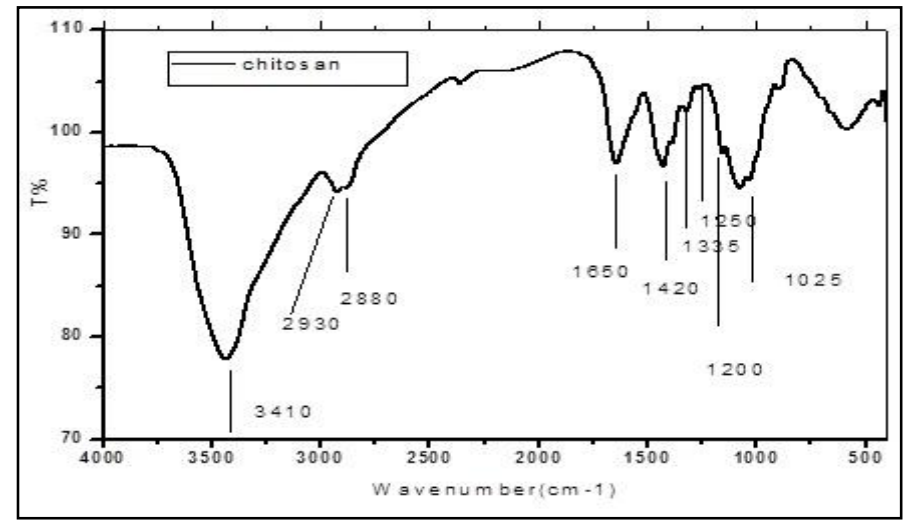

Fig. 2: FTIR spectrum of chitosan

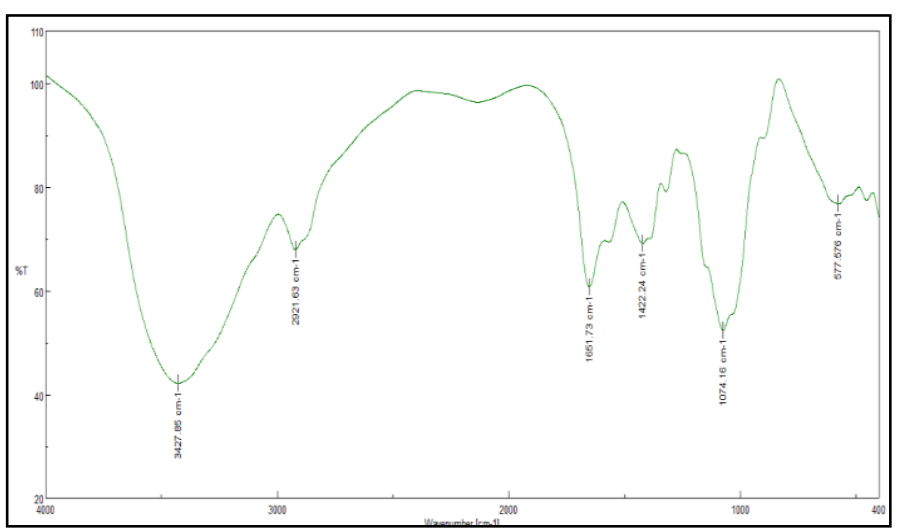

Fig. 3: FTIR spectrum of activated carbon

\section{XRD analysis}

Figures (4 and 5) illustrates the X-ray diffraction profile of the extracted chitosan and activated carbon. Chitosan shows a sharp peaks at $2 \theta=25.3^{\circ}, 27.7^{\circ}$, 
$36.1^{\circ}, 39.2^{\circ}, 41.1^{\circ}, 44.1^{\circ}, 54.5^{\circ}, 56.7^{\circ}, 62.9^{\circ}, 64.1^{\circ}, 69^{\circ}$ and $70^{\circ}$ while activated carbon exhibit very broad diffraction peaks and the absence of a sharp peak reveals a predominantly amorphous structure (Wang and $\mathrm{Lu}$, 1997). There are two broad diffraction peaks at $2 \theta=26.5^{\circ}$ and $46.1^{\circ}$ in spectrum. The appearance of the peak at around $24^{\circ}$ signifies an increasing regularity of crystalline structure (Kasaoka, et al., 1989).

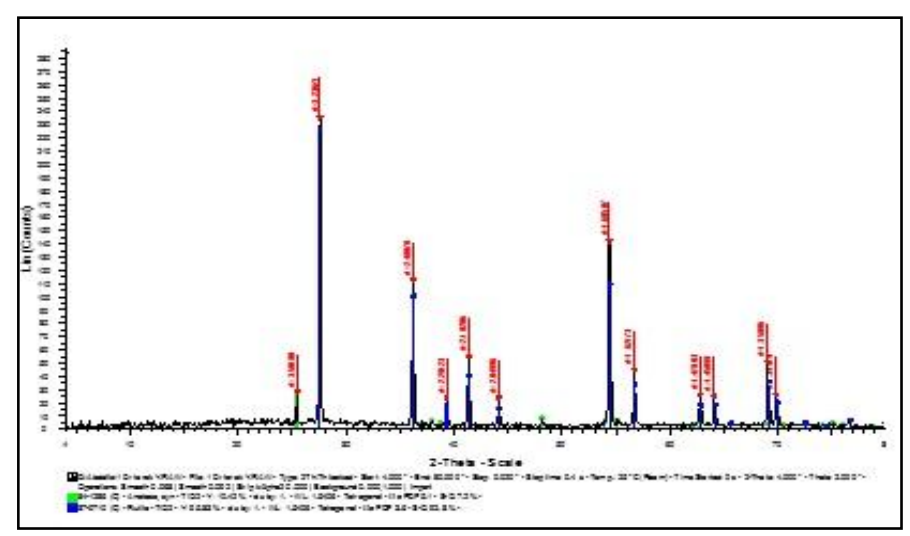

Fig. 4: X-ray of chitosan

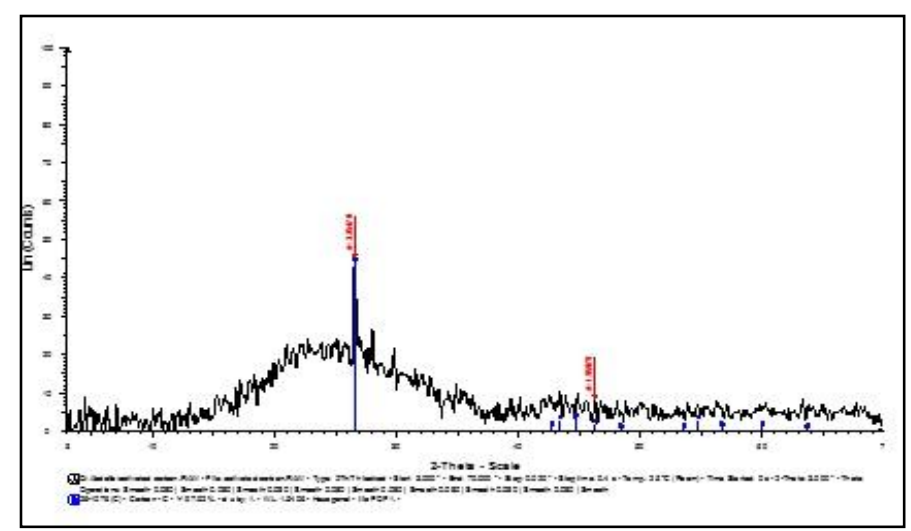

Fig. 5: X-ray of activated carbon

\section{Effect of sorbent dose}

From (Fig. 6) the effect of sorbent dose were studied and the values were changed from 20 to $60 \mathrm{mg} / \mathrm{l}$. In the case of chitosan the highest removal was $88 \%$ for $\mathrm{Zn}$ followed by $85 \%$ for $\mathrm{Fe}$ and finally was $84 \%$ for $\mathrm{Cu}$ at sorbent dose $60 \mathrm{mg} / \mathrm{l}$. While for $\mathrm{AC}$ the maximum removal for $\mathrm{Zn}$ was $86 \%$ and for $\mathrm{Fe}$ and $\mathrm{Cu}$ the percent were similar $80 \%$. The chitosan and AC follow the trend that by increasing the sorbent dose the efficiency also increased.

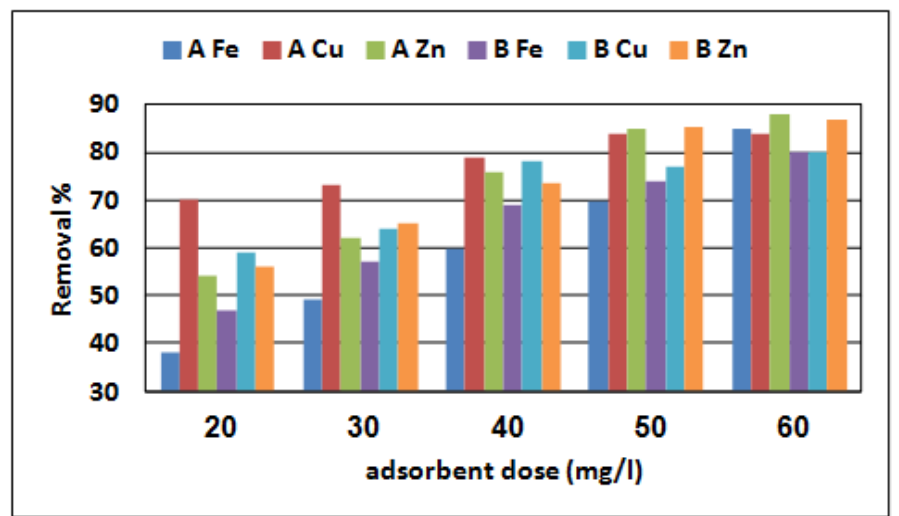

Fig. 6: Effect of adsorbent dose on removal percent of heavy metals from wastewater using (A: chitosan) and (B: activated carbon). 


\section{Effect of $\mathbf{p H}$}

The effect of $\mathrm{pH}$ on the removal efficiency of heavy metal from 4 to 9 is shown in (Fig. 7). The results revealed that, the removal efficiency in chitosan increased by increasing $\mathrm{pH}$ for $\mathrm{Fe}$ and $\mathrm{Zn}$ with the maximum removal rate were $65 \%$ and $72 \%$ at $(\mathrm{pH}=9)$. There was an exception in $\mathrm{Cu}$ the maximum removal was $75 \%$ at $\mathrm{pH}=5$. For $\mathrm{AC}$ the same trend were found, the maximum removal were $55 \%$ and $75 \%$ for $\mathrm{Fe}$ and $\mathrm{Zn}$ at $\mathrm{pH}=9$ but for $\mathrm{Cu}$ was $80 \%$ at $\mathrm{pH}=4$. The results showed that for $\mathrm{Fe}$ and $\mathrm{Zn}$ for chitosan and $\mathrm{AC}$ the efficiency increased by increasing $\mathrm{pH}$ while $\mathrm{Cu}$ give highest efficiency at low $\mathrm{pH}$ in the acid medium.

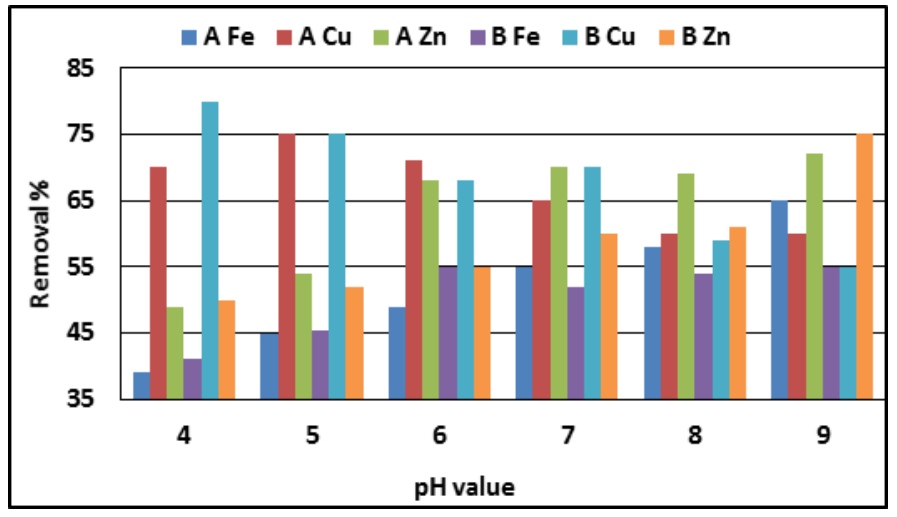

Fig. 7: Effect of $\mathrm{pH}$ on removal percent of heavy metals from wastewater using (A: chitosan) and (B: activated carbon).

\section{Effect of contact time}

In the case of contact time (Fig. 8) the time ranged from 30 to 360 minute.

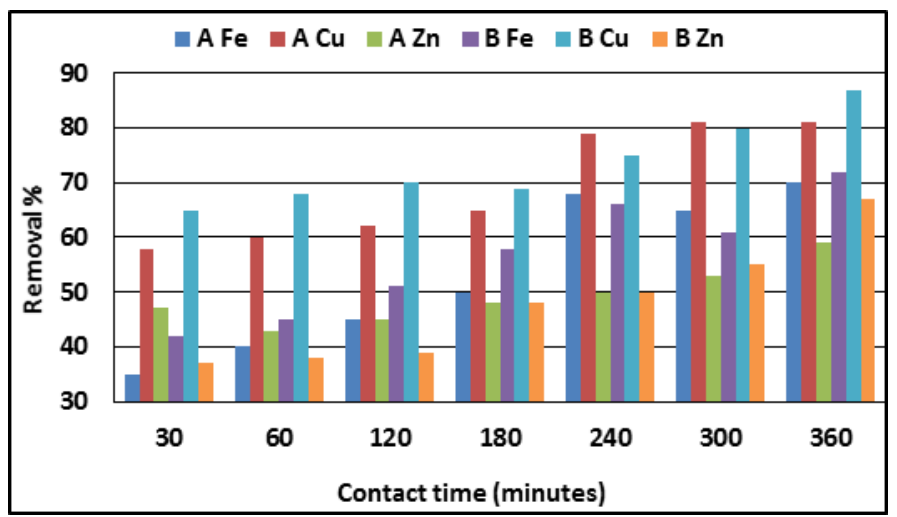

Fig. 8: Effect of contact time on removal percent of heavy metals from wastewater using (A: chitosan) and (B: activated carbon).

For chitosan the results indicate that, the removal efficiency were $70 \%, 81 \%$ and $59 \%$ for $\mathrm{Fe}, \mathrm{Cu}$ and $\mathrm{Zn}$ respectively. The highest value was for $\mathrm{Cu}$ and the lowest for $\mathrm{Zn}$. In A.C the removal efficiency for $\mathrm{Fe}, \mathrm{Cu}$ and $\mathrm{Zn}$ were $72 \%, 87 \%$ and $55 \%$ respectively, so the lowest efficiency was for $\mathrm{Zn}$ and the highest efficiency was for $\mathrm{Cu}$. All the results can be concluded as by increasing the contact time the removal efficiency increased.

\section{Effect of temperature}

As seen in (Fig. 9) the effect of temperature on the removal of $\mathrm{Fe}, \mathrm{Cu}$ and $\mathrm{Zn}$ by chitosan were $82 \%, 80 \%$ and $65 \%$ respectively. Also for Chitosan as the 
temperature increased the efficiency decreased except for $\mathrm{Fe}$. In $\mathrm{AC} \mathrm{Fe}, \mathrm{Cu}$ and $\mathrm{Zn}$ showed the removal efficiency $73 \%, 70 \%$ and $58 \%$ respectively, for AC all the metals follow the same trend that, the efficiency increased by decreasing temperature.

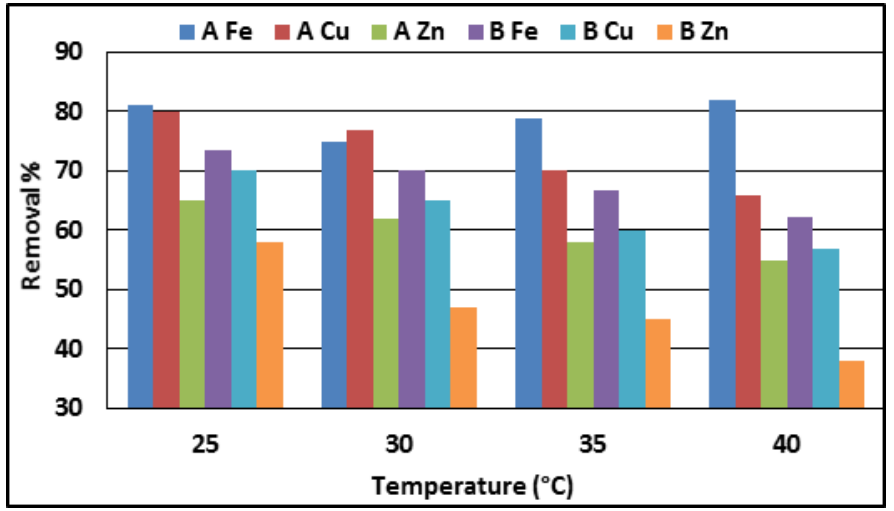

Fig. 9: Effect of temperature on removal percent of heavy metals from wastewater using (A: chitosan) and (B: activated carbon).

\section{Effect of initial metal concentration}

In the case of study the effect of initial metal concentration (Fig. 10). The results showed that, the maximum removal efficiency for Fe was $58 \%$ at $5 \mathrm{mg} / \mathrm{l}$ and for $\mathrm{Cu}$ and $\mathrm{Zn}$ were $68 \%$ and $69 \%$ at $10 \mathrm{mg} / \mathrm{l}$ for chitosan. Also, for $\mathrm{AC}$ the maximum removal efficiency were $74 \%$ and $70 \%$ for $\mathrm{Fe}$ and $\mathrm{Cu}$ at $5 \mathrm{mg} / \mathrm{l}$ while for $\mathrm{Zn}$ was $78 \%$ at $10 \mathrm{mg} / \mathrm{l}$. As showed the efficiency decreased as the concentration increased.

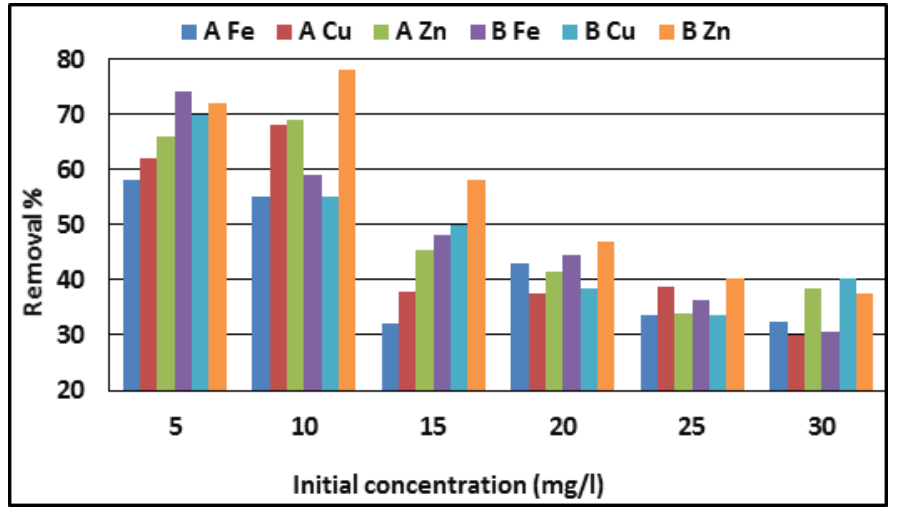

Fig. 10: Effect of initial concentration on removal percent of heavy metals from wastewater using (A: chitosan) and (B: activated carbon).

\section{Application study}

Table (4) illustrate the effect of chitosan and active carbon on heavy metals removal in the polluted water collected from River Nile. For chitosan the highest removal was $93 \%$ for $\mathrm{Fe}$ at El-Kanater El-Khiria followed by $\mathrm{Pb} 92 \%$ at Helwan then $86 \%$ for $\mathrm{Cu}$ at El-Kanater El-Khiria and $75 \%$ for $\mathrm{Zn}$ at Helwan, finally $57 \%$ for $\mathrm{Mn}$ at Helwan. So the removal efficiency of heavy metals from the polluted water using chitosan were in following order: $\mathrm{Fe}>\mathrm{Pb}>\mathrm{Cu}>\mathrm{Zn}>\mathrm{Mn}$. On the other hand $\mathrm{AC}$ give highest removal efficiency $95.8 \%$ for $\mathrm{Mn}$ at Helwan then $95.1 \%$ for $\mathrm{Cu}$ at El-Kanater El-Khiria and $87 \%$ for Fe at El-Kanater El-Khiria followed by $84 \%$ for Pb at Helwan lastly $83 \%$ for $\mathrm{Zn}$ a Helwan. Also the effect of AC on heavy metal removal follow the order: $\mathrm{Mn}>\mathrm{Cu}>\mathrm{Fe}>\mathrm{Pb}>\mathrm{Zn}$. 
Table 4. Metal removal efficiency of heavy metals from water samples collected from River Nile at Greater Cairo using chitosan and activate carbon

\begin{tabular}{|l|l|c|c|c|c|c|c|}
\hline \multirow{2}{*}{ Metals } & \multicolumn{2}{|c|}{ Polluted sources } & \multicolumn{3}{|c|}{ Chitosan } & \multicolumn{3}{c|}{ Activated carbon } \\
\cline { 3 - 8 } & & $C o$ & $C f$ & $R \%$ & $C o$ & $C f$ & $R \%$ \\
\hline \multirow{3}{*}{$\mathrm{Fe}$} & Helwan & 0.371 & 0.025 & 93.261 & 0.371 & 0.050 & 86.523 \\
\cline { 2 - 8 } & Hawmdia & 0.282 & 0.023 & 91.844 & 0.282 & 0.040 & 85.816 \\
\cline { 2 - 8 } & El-Kanater El-Khiria & 0.247 & 0.015 & 93.927 & 0.247 & 0.030 & 87.854 \\
\hline \multirow{3}{*}{$\mathrm{Mn}$} & Helwan & 0.241 & 0.102 & 57.676 & 0.241 & 0.010 & 95.851 \\
\cline { 2 - 8 } & Hawmdia & 0.211 & 0.111 & 47.393 & 0.211 & 0.020 & 90.521 \\
\cline { 2 - 8 } & El-Kanater El-Khiria & 0.185 & 0.106 & 42.703 & 0.185 & 0.020 & 89.189 \\
\hline $\mathrm{Cu}$ & Helwan & 0.132 & 0.025 & 81.061 & 0.132 & 0.011 & 91.667 \\
\cline { 2 - 8 } & Hawmdia & 0.115 & 0.022 & 80.870 & 0.115 & 0.015 & 86.957 \\
\cline { 2 - 8 } & El-Kanater El-Khiria & 0.145 & 0.020 & 86.207 & 0.145 & 0.007 & 95.172 \\
\hline $\mathrm{Zn}$ & Helwan & 0.736 & 0.180 & 75.543 & 0.736 & 0.120 & 83.696 \\
\cline { 2 - 8 } & Hawmdia & 0.685 & 0.175 & 74.453 & 0.685 & 0.130 & 81.022 \\
\cline { 2 - 8 } & El-Kanater El-Khiria & 0.502 & 0.170 & 66.135 & 0.502 & 0.101 & 79.880 \\
\hline \multirow{3}{*}{$\mathrm{Pb}$} & Helwan & 0.767 & 0.055 & 92.829 & 0.767 & 0.120 & 84.355 \\
\cline { 2 - 8 } & Hawmdia & 0.490 & 0.045 & 90.816 & 0.490 & 0.090 & 81.633 \\
\cline { 2 - 7 } & El-Kanater El-Khiria & 0.010 & 0.001 & 90.000 & 0.010 & 0.002 & 80.000 \\
\hline
\end{tabular}

\section{CONCLUSION}

River Nile water pollution by heavy metals in Egypt is a very serious problem because of their dangerous effect on human. This study give solution in heavy metals removal using materials that can pollute our environment. Chitosan prepared from wastes of shrimp and activated carbon from rice husk were used for removal of heavy metal. The present results give an indication for good removal effect of the two adsorbents.

\section{REFERENCES}

AOAC (2007). Official Methods of Analysis of the Association of Official Analytical Chemists. $18^{\text {th }}$ Edn. Association of Official Analytical Chemists, Washington, DC., USA.

Baskaran P. K.; Venkatraman, B. R.; Hema, M. and Arivoli, S. (2010). Adsorption studies of copper ion by low cost activated carbon. J. Chem. Pharm. Res., 2 (5): 642-655.

Dutta, P. K.; Dutta, J. and Tripathi, V. S. (2004). Chitin and chitosan: Chemistry, property and application. J. Sci. Ind. Res., 63: 20-31.

Edwin, V.A. (2008). Surface modification of activated carbon for enhancement of nickel (II) adsorption. E-J. Chem., 5 (4): 814-819.

Ghannam, H. E.; Talab, A.S.; Dolganova, N. V.; Hussein, A. M. and Abdelmaguid, N. M. (2016). Characterization of chitosan extracted from different crustacean shell wastes. J. Appl. Sci., 16: 454-461.

I.S.I., (1989). Indian Standard Institution, Activated Carbon, Powdered and GranularMethods of sampling and its tests, Bureau of Indian Standards, New Delhi, 1989, IS 877.

Jyotsna, G.; Krishna, K.; Chitra, R. and Vinod, K. (2005). Removal of lead (II) by adsorption using treated granular activated carbon: Batch and column studies. J. Hazard. Mater, 125 (1-3), 17: 211-220.

Kasaoka, S.; Sakata, Y.; Tanaka, E. and Naitoh, R. (1989). Preparation of activated fibrous carbon from phenolic fabric and its molecular-sieve properties. Int. Chem. Eng., 29 (1):101-114. 
Menya, E.; Olupota, P.W.; Storzc, H.; Lubwamaa, M. and Kirosd, Y. (2018). Production and performance of activated carbon from rice husks for removal of natural organic matter from water: A review. Chem. Eng. Res. Des., 129: 271296.

Mohanasrinivasan, V.; Mishra, M.; Paliwal, J. S.; Singh, S. K.; Selvarajan, E.; Suganthi, V. and Devi, C.S. (2014). Studies on heavy metal removal efficiency and antibacterial activity of chitosan prepared from shrimp shell waste. Biotech., 4: 167-175.

Sajida, M.; Mazen, Kh. N.; Ihsanullaha, N. B. and Abdalghaffar, M. O. (2018). Removal of heavy metals and organic pollutants from water using dendritic polymers based adsorbents: A critical review. Sep. Purif. Technol., pp.400-423.

Struszczyk, H. (1987). Microcrystalline chitosan. I. Preparation and properties of microcrystalline chitosan. J. Applied Polym. Sci., 33: 177-189.

Toan, N.V. (2009). Production of chitin and chitosan from partially autolyzed shrimp shell materials. The Open Biomaterials J., 1: 21-24.

Wang, J. and Zhuang, S. (2018). Removal of various pollutants from water and wastewater by modified chitosan adsorbents. Crit. Rev. Environ. Sci. Technol., 2331-2386.

Wang, J. C. and Kinsella, J. E. (1976). Functional properties of novel proteins: Alfalfa leaf protein. J. Food Sci., 41: 286-292.

Wang, S. B. and Lu, G. Q. (1997). Effects of Oxide Promoters on Metal Dispersion and Metal-Support Interactions in Ni Catalysts Supported on Activated Carbon. Ind. Eng. Chem. Res., 36: 5103. 